\title{
Terrestrial vertebrates from the Sarmatian (late Serravallian) of the Central Paratethys - the fossil site of Gratkorn (Styrian Basin, Austria)
}

\author{
Madelaine Böhme • Jérôme Prieto • Martin Gross
}

Received: 12 December 2013 / Accepted: 16 December 2013 /Published online: 11 February 2014

(C) Senckenberg Gesellschaft für Naturforschung and Springer-Verlag Berlin Heidelberg 2014

The Paratethys Sea represents a huge landlocked water body of western Eurasia, which evolved during the Cenozoic era from open to restricted marine conditions towards brackish and lacustrine basins (Rögl and Steininger 1983). Due to the endemic evolution of Paratethyan biota and the tectonics of the Alpine orogeny, chronostratigraphic correlations and basin evolution are still partly a matter of debate and a subject of intense scientific research.

Despite the mainly marine or lacustrine sedimentation (Steininger et al. 1985), fossils of continental biota are not rare in deposits in the Paratethyan realm. Notably, terrestrial vertebrates have been known for a long time (e.g. Eichwald 1835), but well-documented excavations and faunas are rare or absent from many stratigraphic stages and basins. This is especially true for the Sarmatian regional stage when the Paratethys was becoming isolated from the world oceans (Piller et al. 2007). This chronostratigraphic stage is crucial,

This article is a contribution to the special issue "The Sarmatian vertebrate locality Gratkorn, Styrian Basin."

M. Böhme ( $\)$

Fachbereich Geowissenschaften, Eberhard Karls Universität

Tübingen, Sigwartstraße 10, 72076 Tübingen, Germany

e-mail: m.boehme@ifg.uni-tuebingen.de

M. Böhme

Senckenberg Center for Human Evolution and Palaeoenvironment (HEP), Sigwartstraße 10, 72076 Tübingen, Germany

\section{J. Prieto}

Department of Earth- and Environmental Science, Palaeontology, Ludwig-Maximilians-University Munich, Richard-Wagner-Str. 10, 80333 Munich, Germany

e-mail: j.prieto@1rz.uni-muenchen.de

\section{Gross}

Department for Geology \& Palaeontology, Universalmuseum

Joanneum, Weinzöttlstrasse 16, 8045 Graz, Austria

e-mail: martin.gross@museum-joanneum.at because the Sarmatian sensu stricto (=Volhynian and early Bessarabian) represents the last period with a uniform marine biofacies in the entire Paratethys, extending from the Styrian Basin in the west to the Lake Aral in the east (Steininger and Wessely 2000). While the deposits cover a huge area, terrestrial biota are still a rarity, and those from the early to late Sarmatian transition (Volhynian-Bessarabian transition) virtually unknown.

The discovery of the Gratkorn fossil site due to geologic mapping in 2005 gives a unique opportunity to study continental ecosystems of this specific time horizon (12.212.0 Ma, early to late Sarmatian transition). Systematic palaeontologic excavations starting in 2006 have been carried out in a cooperation between the Universalmuseum Joanneum (Graz), the Ludwig Maximillians Universität München, and the Eberhard Karls Universität Tübingen. Besides abundant fossils of plants (leaf- and carpoflora), molluscs (gastropods and mussels), and arthropods (insects, ostracodes, and crabs), more than 1,500 specimens of vertebrates have so far been excavated. These fossils cover all major groups of vertebrates, namely fishes, amphibians, reptiles, birds, and mammals, rendering Gratkorn a benchmark locality for continental biota from the Sarmatian of the Central Paratethys.

This special issue is dedicated to Prof. Dr. Friedrich Franz Steininger on the occasion of his 75th birthday in 2014, and in honour of his noteworthy scientific contributions to chronostratigraphy, palaeogeography, and biofacies of the Paratethys Sea. Twelve publications have been brought together summarising the first nearly 10 years of research at Gratkorn. They deal with the geology of the Gratkorn locality, the vertebrate taphonomy, and selected aspects of vertebrate taxonomy and ecology. Further scientific contributions to Gratkorn, e.g. the macro-flora and the carnivore mammals, are in preparation and will shortly be published in a forthcoming issue of Palaeobiodiversity and Palaeoenvironments. 
Martin Gross, Madelaine Böhme, Philipe Havlik, and Manuela Aiglstorfer: "The late Middle Miocene (Sarmatian s.str.) fossil site Gratkorn - the first decade of research, geology, stratigraphy and vertebrate fauna".

Gross, Böhme, Havlik, and Aiglstorfer summarise the history of research of the Gratkorn locality, the geological background as well the stratigraphy. So far, 65 vertebrate taxa have been documented from a rapidly accumulating floodplain paleosol. The authors describe new sedimentological profiles, interpret the litho- and biofacies of the Gratkorn section, and emphasise that time-averaging is low and the taphocoenosis excavated from the paleosol well reflects the original vertebrate community. Integrated stratigraphic analysis place the Gratkorn site at the beginning of the late Sarmatian, to about 12.2-12.0 Ma (late Middle Miocene). (Palaeobio Palaeoenv 94(1). doi:10.1007/s12549013-0149-1

Madelaine Böhme and Davit Vasilyan: "Ectothermic vertebrates from the late Middle Miocene of Gratkorn (Austria, Styria)".

Böhme and Vasilyan studied the ectothermic vertebrate fauna of Gratkorn. They describe two fish (Leuciscinae indet., Gobiidae indet.), eight amphibian (Triturus aff. vulgaris, Salamandra sansaniensis, Chelotriton aff. paradoxus, Rana sp., Pelophylax sp., Latonia sp., Bufotes cf. viridis, Pelobates sanchizi) and 17 reptile taxa (Scincidae indet., Lacerta s.l. sp. 1 to 3, Miolacerta tenuis, ?Edlartetia sp., Gekkonidae indet., Varanus sp., Ophisaurus spinari, Colubrinae sp. 1 and sp. 2, Natricinae sp., Naja sp., Clemmydopsis turnauensis, Chelydropsis murchisonae, Testudo cf. steinheimensis, Testudo cf. kalksburgensis), of which reptiles (especially scincomorphs) are the most abundant group. Some fossorial to semi-fossorial species are represented by semi-associated skeletons, suggesting rapid burial. The herpetofauna from the paleosol horizon reflects a variety of habitats, including short-lived ponds, streams or rivulets in the close vicinity, relatively open landscapes, and a dry, semi-arid climate (MAP $486 \pm 252 \mathrm{~mm}$ ). In a short discussion of Sarmatian herpetofauna and climate, the authors conclude semi-arid conditions during the Sarmatian stage, interrupted by a mid-Sarmatian humidity peak at around 12 Ma. (Palaeobio Palaeoenv 94(1). doi:10.1007/s12549-0130143-7

Ursula B. Göhlich and Martin Gross: "The Sarmatian (late Middle Miocene) avian fauna from Gratkorn, Austria"

Göhlich and Gross studied the rare bird fossils from Gratkorn. Fifteen isolated specimens allow the recognition of four different taxa, belonging to the largely sedentary phasanids
(Miogallus altus, cf. Palaeocryptonyx edwardsi, cf. Palaeocryptonyx sp.) and the mousebird Necrornis cf. palustris. All these taxa have been known before from Middle Miocene deposits in Europe, but they are proven in Austria for the first time. (Palaeobio Palaeoenv 94(1). doi:10.1007/ s12549-013-0139-3

Manuela Aiglstorfer, Ursula B. Göhlich, Madelaine Böhme, and Martin Gross: "A partial skeleton of Deinotherium from the late Middle Miocene locality Gratkorn (Austria)"

Aiglstorfer, Göhlich, Böhme, and Gross report the discovery of a disarticulated, though still roughly associated, partial Deinotherium skeleton, one of the very few finds of this genus. They observe important anatomical postcranial features differentiating Deinotherium from Prodeinotherium at the genus level. Due to the lack of the diagnostically important $\mathrm{p} / 3$, the medium-sized skeleton can only be assigned to Deinotherium levius vel. giganteum. (Palaeobio Palaeoenv 94(1). doi:10.1007/s12549-013-0140-x

Manuela Aiglstorfer, Kurt Heissig, and Madelaine Böhme: "Perissodactyla from the late Middle Miocene locality Gratkorn (Austria)"

Fossils of perissodactyls are rare in Gratkorn. Aiglstorfer, Heissig, and Böhme describe all recorded materials and identified three rhinocerotid species (Aceratherium sp., Brachypotherium brachypus, Lartetotherium sansaniense), as well as a chalicotherid (Chalicotherium goldfussi) and an equid (Anchitherium sp.). The authors conclude that the perissodactyl assemblage fits well with an ecosystem of riparian woodland and diverse habitats from active rivers to drier more open environments. (Palaeobio Palaeoenv 94(1). doi:10.1007/ s12549-013-0138-4

Manuela Aiglstorfer, Gertrud E. Rössner, and Madelaine Böhme: "Dorcatherium naui and pecoran ruminants from the late Middle Miocene locality Gratkorn (Austria)"

Aiglstorfer, Rössner, and Böhme provide a comprehensive description of tragulids and pecoran ruminants, the most abundant large mammals at Gratkorn. They describe six species, namely Dorcatherium naui, Micromeryx flourensianus, ?Hispanomeryx sp., Euprox furcatus, Palaeomerycidae gen. et sp. indet., and Tethytragus sp. The tragulid D. naui represents one of the oldest records for this species. They confirm the assignation of $D$. naui to a selenodont lineage (together with D. guntianum) distinct from a bunoselenodont lineage (including $D$. crassum). The moschid ruminant ?Hispanomeryx $\mathrm{sp}$. is the first described record of this genus from Central Europe, similar to the bovid Tethytragus sp. The second moschid, 
Micromeryx flourensianus, and the deer Euprox furcatus are regionally well-represented taxa, but comprise their first records from Styria. A single bone of a large palaeomerycid ruminant is difficult to assign to species level. (Palaeobio Palaeoenv 94(1). doi:10.1007/s12549013-0141-9

Chiara Angelone, Jérôme Prieto, and Martin Gross: "Complement to the study of the pikas (Lagomorpha, Ochotonidae) from Gratkorn"

Angelone, Prieto, and Gross provide an update of the lagormorphs from Gratkorn. Besides the previously recorded ochotonid Prolagus oeningensis, they describe in detail cf. Eurolagus fontannesi and report for the first time an Ochotonidae gen. et sp. indet. In a discussion of the late Middle Miocene ochotonid record from Europe, they recognize some primitive morphologic characteristics in $P$. oeningensis from Gratkorn. Furthermore, the authors suggest that the forms assigned to Eurolagus fontannesi in the fossil record are in urgent need of revision. This is an important step to decide on the stratigraphic range (late Middle Miocene?) of the species. Interestingly, the few remains of the third pika (Ochotonidae indet.) belong to a so far unknown ochotonid. (Palaeobio Palaeoenv 94(1). doi:10.1007/s12549013-0146-4

Jérôme Prieto, Chiara Angelone, Isaac Casanovas-Vilar, Martin Gross, Janós Hír, Lars W. van den Hoek Ostende, Lutz Christian Maul, and Davit Vasilyan: "The small mammals from Gratkorn: an overview"

Prieto, Angelone, Casanovas-Vilar, Gross, Hir, van den Hoek Ostende, Maul and Vasilyan present a taxonomic, stratigraphic, and ecologic evaluation of the Gratkorn small mammal assemblage. The 19 taxa belong to Schizogalerix voesendorfensis, Galericinae gen. et sp. indet., Desmanodon fluegeli, Dinosorex sp., cf. Myotis sp., "Cricetodon" fandli, Megacricetodon minutus, Eumyarion sp., Spermophilinus bredai, Blackia sp., Forsythia gaudryi, Albanensia albanensis, Muscardinus aff. sansaniensis, Miodyromys sp., Keramidomys sp., Euroxenomys minutus minutus, Prolagus oeningensis, cf. Eurolagus fontannesi and Ochotonidae indet. The authors propose a preliminary stratigraphic ordering of late Middle and earliest Late Miocene small mammal assemblages from Central Europe, but the still insufficient knowledge of evolutionary lineages hamper the establishment of a straightforward biozonation. Based on taphonomic criteria (corrosion and presence of pellets), the authors suggest that most small mammals have been accumulated by nocturnal raptors, emphasising the extremely rapid accumulation of the fossils in the upper part of the paleosol. (Palaeobio Palaeoenv 94(1). doi:10. 1007/s12549-013-0147-3

Jérôme Prieto, Isaac Casanovas-Vilar, and Martin Gross: "Euroxenomys minutus minutus (Rodentia, Castoridae) from Gratkorn (Austria, Styria)"

Prieto, Casanovas-Vilar, and Gross provide a description of the beaver remains (isolated teeth, a palate and a fragmentary skull) from Gratkorn. All materials belong to a single smallsized species (Euroxenomys minutus minutus), well known by dental and postcranial remains from other Austrian localities. The important fragmentary skull from Gratkorn is too damaged to provide a deeper insight into the cranial anatomy of Euroxenomys. (Palaeobio Palaeoenv 94(1). doi:10.1007/ s12549-013-0148-2

Philipe Havlik, Manuela Aiglstorfer, Annika K. Beckmann, Martin Gross and Madelaine Böhme: "Taphonomical and ichnological considerations on the late Middle Miocene locality Gratkorn (Styria, Austria) with focus on Large Mammal Taphonomy"

Havlik, Aiglstorfer, Beckmann, Gross, Keuper, and Böhme present a taphonomic study of the fossiliferous paleosol from Gratkorn. The low total rare earth element (REE) content of mammal bones and teeth, and the preserved aragonitic shells of gastropods, point to a low level of diagenetic alteration. The degree of large mammal disarticulation and bone fragmentation is high, interpreted to be induced by hunting, scavenging, trampling, and neotectonic movements. The lack of abrasion on bones, the discovery of some semi-articulated parts of skeletons, and the Voorhies analysis suggest no fluvial transportation and a local accumulation of large mammal bones by scavengers. The taphocoenosis is interpreted to be largely autochthonous and contemporaneous without any significant time averaging. (Palaeobio Palaeoenv 94(1). doi:10.1007/ s12549-013-0142-8

Manuela Aiglstorfer, Hervé Bocherens, and Madelaine Böhme: "Large mammal ecology in the late Middle Miocene locality Gratkorn (Austria)"

Applying $\delta^{18} \mathrm{O}_{\mathrm{CO} 3}, \delta^{13} \mathrm{C}$ and ${ }^{87} \mathrm{Sr} /{ }^{86} \mathrm{Sr}$ measurements on tooth enamel, Aiglstorfer, Bocherens, and Böhme evaluate the diet and mobility of large herbivorous mammals from Gratkorn. Most investigated species show typical carbon and oxygene isotope values for browsing exclusively on $\mathrm{C} 3$ vegetation in a mesic/woodland environment. The tragulid Dorcatherium naui was most likely frugivore to a certain degree. The $\delta^{18} \mathrm{O}$ and $\delta^{13} \mathrm{C}$ variation among the taxa indicate different and probably species-constant ecological niching. The moschid 
Micromeryx flourensianus might have fed occasionally on fruits, while the deer Euprox furcatus represents a typical subcanopy browsing taxon. The proboscidean Deinotherium browsed on higher canopy plant remains as did the bovid Tethytragus sp. Generally higher values for $\delta^{18} \mathrm{O}$ and $\delta^{13} \mathrm{C}$ of the rhino Lartetotherium sansaniense indicate feeding in a more open environment, while the suid Listriodon splendens was a browsing species with a considerable input of fruits (and maybe grass), whereas the second suid Parachleuastochoerus steinheimensis might have fed to a certain degree on roots. Distinct differences in ${ }^{87} \mathrm{Sr} /{ }^{86} \mathrm{Sr}$ values indicate that most of the measured larger mammal individuals (Deinotherium, $P$. steinheimensis, E. furcatus, $L$. sansaniense and to a minor degree maybe $L$. splendens) were not permanent residents of the area around Gratkorn but rather inhabited a wider area of the Styrian Basin and the higher altitudes of the Eastern Alps. (Palaeobio Palaeoenv 94(1). doi:10.1007/s12549-013-0145-5

The following contribution will be published as an additional contribution to the special issue in a subsequent regular issue:

Jan van der Made, Jérôme Prieto, Manuela Aiglstorfer, Madelaine Böhme, and Martin Gross: "Taxonomic study of the pigs (Suidae, Mammalia) from the late Middle Miocene of Gratkorn (Austria, Styria)".

Van der Made, Prieto, Aiglstorfer, Böhme and Gross provide a description of the suid dental remains from Gratkorn, which belong to two species: Listriodon splendens and Parachleuastochoerus steinheimensis. Whereas the first is a well-known species from Sarmatian deposits, the generic affinities of the second species are discussed by giving a detailed review of the evolution of European Tetraconodontinae. The authors conclude that the genus Parachleuastochoerus includes the species $P$. steinheimensis (with the subspecies $P$. $s$. olujici), $P$. huenermanni and P. crusafonti. (Palaeobio Palaeoenv. doi:10.1007/s12549-014-0152-1)

Acknowledgements We wish to express our gratitude to the Editor-inChief Peter Königshof and the Managing Editor Sinje Weber for the opportunity to realise this issue, the perfect organisation, manifold support and patience during different stages of this process. Furthermore, we want to thank all colleagues involved as reviewers of different articles (in alphabetical order): Pierre-Olivier Antoine, Beatriz Azanza, Anna K. Behrensmeyer, Margery C. Coombs, Loic Costeur, Gudrun Höck, Fritz Ebner, Mathias Harzhauser, Kurt Heissig, Kees Hordijk, Olivier Maridet, Georgi N. Markov, Thomas Mörs, Maeva J. Orliac, Gerald Mayr, Pablo Peláez-Campomanes, Marco Pavia, Martin Pickford, Jean-Claude Rage, Achim G. Reisdorf, Sevket Sen, and Krister T. Smith.

\section{References}

Eichwald CE (1835) De Pecorum et Pachydermorum reliquiis fossilibus, in Lithuania, Volhynia et Podolia repertis. Nova Acta Academiae Caesareae Leopoldino-Carolinae Germanicae Naturae Curiosorum 17(2):677-760

Piller WE, Harzhauser M, Mandic O (2007) Miocene Central Paratethys stratigraphy - current status and future directions. Stratigraphy 4 : 151-168

Rögl F, Steininger FF (1983) Vom Zerfall der Tethys zu Mediterran und Paratethys. Die neogene Paläogeographie und Palinspastik des zirkum-mediterranen Baumes. Ann Naturhist Mus Wien 85A:135163

Steininger FF, Wessely G (2000) From the Tethyan Ocean to the Paratethys Sea: Oligocene to Neogene stratigraphy, paleogeography and paleobiogeography of the circum-Mediterranean region and the Oligocene to Neogene Basin evolution in Austria. Mitt Österr Geol Ges 92:95-116

Steininger FF, Senes J, Kleemann K, Rögl F (eds.) (1985) Neogene of the Mediterranean Tethys and Paratethys. Stratigraphic correlation tables and sediment distribution maps. Vol. 1: XIC + 189, 80 fig., 10 colour maps. Vol. 2: XXV + 524 (Inst. Paleontol.) Vienna 